\title{
The Self and the Other in Philip Massinger's "The Renegado, the Gentleman of Venice": A Structural View
}

\author{
Hana Fathi Farajallah \\ Department of English Language and Literature, Ajloun University College, Balqa’ Applied University, Ajlun, Jordan \\ Amal Riyadh Kitishat \\ Department of English Language and Literature, Ajloun University College, Balqa’ Applied University, Ajlun, Jordan
}

\begin{abstract}
Renaissance England (1500-1660) is the most flourishing era of English history which testified the emergence of classical humanistic arts. Of course, drama is a literary genre that prospered, then, to entertain the interests of the Royal ruling families, especially Queen Elizabeth 1 (1558-1603) and her successor King James 1 (1603-25), as theatres were built in London along with dramatic performances held in the courts like masquerades. This study aims at showing the distortion of Islam in Philip Massinger's "The Renegado or The Gentleman of Venice", via tackling the theme of "the self and the other" and analyzing the structure of the play. Why not, and English Renaissance citizens love to watch the non-Christians, the misbelievers, humiliated and undermined. Massinger, among other Elizabethan dramatists like William Shakespeare, uses the art of tragicomedy to show the Western hatred, which is "the self", of the Oriental Islam that is in turn "the other".
\end{abstract}

Index Terms - binary opposition, Islam distortion, orientalism, Philip Massinger, renegade, the self and the other

\section{INTRODUCTION}

Philip Massinger is an English Renaissance dramatist and poet who was born in 1583, Salisbury. Massinger is the son of Arthur Massinger who was a servant and agent of Henry Herbert, the Second Earl of Pembroke, and of William Herbert, the third, to whom Massinger wrote his dedications and minor poems. Ann is Massinger's mother (Holland, 1986)

Massinger received his primary education at Salisbury Grammar School, entering Oxford in 1602 where he was compelled to leave, without having any degree, due to financial problems associated with his father's death in 1603 (Stapleton, 1983).

What connects Massinger to the theatre is a letter sent by him and other two dramatists, who were imprisoned for a debt, to Philip Henslowe, the manager of The Rose Theatre, asking him to release them by paying their debts. Henslowe approved on condition that they should join his workshop in turn (Fraser, 1976).

It is strange to find Massinger's inescapable poverty (Carter, 1995) although he was a member of the King's [James 1's and then Charles 1's Company]. He succeeded John Fletcher (1579-1625), who died of a plague, in holding the chair of that company in 1625, writing plays that were performed at The Globe and The Blackfriars Theatres ( Drabble, 1987).

Documents have not mentioned any pieces of information about Massinger's wife or children or even being married, so he could be a bachelor because of his poverty. Massinger died in 1640, London where he was buried beside Fletcher's grave at South work Cathedral (Burgess, 1987).

Massinger wrote around fifty-five plays of which twenty-two have been lost. He is mostly attracted to tragicomedy, of which "The Renegado" is an instant, due to Fletcher's influence upon him, who [Fletcher] in turn was influenced by William Shakespeare (Cuddon, 1998).

\section{Characters in Philip Massinger’s the Renegade: The Gentle Man OF Venice and the OrIEntal Setting}

Before discussing the theme and the structure of this play, it is worthy first to give the readers a summary which is built on the reading of this play. The Renegado or The Gentleman of Venice is a tragicomedy which consists of five acts. The hero is the Italian pirate Antonio Grimaldi, "the renegade" as he converts from Christianity to Islam. It is because of this conversion he was considered a "renegade". According to Oxford Dictionary, "renegade" is a Spanish word derived from the verb "renegade", meaning that someone changes his / her dogma or religion adopting another (Hornby, 1995). This play is set in an Oriental setting in north Africa that is Tunis. Grimaldi kidnapped an Italian lady whose name is Paulina, fleeing to Tunis where the play is set. Grimaldi sold Paulina to Asambeg, the Viceroy of Tunis. Vitelli, a Venetian gentleman, "Paulina's brother" came to Tunis to look for his kidnapped sister. Being disguised as a merchant, Vitelli knew that his sister was staying in the 'harem', a place where Muslim women live, of Asambeg. 
Paulina protected her honor and virtue by not allowing anybody to touch her. In the meanwhile, a Turkish [Muslim] Princess, named Donusa, fell in love with the Christian Venetian merchant, Vitelli, refusing the proposal of the Aleppo suitor, Basha Mustafa. She invited Vitelli to come to visit her in the palace, bringing with him some religious famous paintings of Michael Angelo that he considered the best, to which nothing can be equaled. However, the Turkish princess unveiled her face to show Vitelli that her beauty was not inferior to the beauty of those religious paintings. Actually, Vitelli went to the palace without knowing the real motive of Donusa's invitation, telling himself if she fell in love with him, he would ask her help in releasing his sister Paulina from Asambeg's capture. When Vitelli spoke the keyword, he was allowed to enter the palace where he had a sexual affair with Donusa. Feeling sinful, Vitelli confessed to the Jesuit Francisco, deciding to repel Donusa's advances in the next meeting that he promised her to see. However, the writer presents a distorted image of the Muslim character, Donusa, as sensual who was surprised by Vitelli's strange reaction, attempted to seduce him, who [both of them] were overheard by the Asambeg, ordering their death. Donusa told the Asambeg that she was trying to make Vitelli turn from Christianity to Islam before getting married, so the Asambeg gave her another chance to do so, otherwise, both of them would be killed. The distortion of the image reached its highest level when Massinger presents the Christian character as committed to his religion, whereas the Islamic character "Donusa" was presented negatively; she couldn't convince Vitelli to be a Muslim; instead, she turned, herself, a Christian, fleeing with Vitelli from Tunis to Italy. The Jesuit Francisco reconverted the renegade Grimaldi to Christianity and Paulina ran away too. The play ended with a dialogue of the powerless Viceroy of Tunis.

\section{THE OPPOSITION OF THE SELF AND THE OTHER}

This play, among other Elizabethan and Jacobean plays, indicates the ideology of the self as opposed to the other that is firstly initiated by Edward Said (1978) in his book, "Orientalism" who says that "orientalism also tries to show that European culture gained in strength and identity by setting itself off against the Orient as a sort of surrogate and even underground self" (p.3). Massinger wrote this play to satisfy the Jacobean Audience's desire for seeing Muslims weak, helpless, voluptuous and humiliated by Christians (Chew, 1965). Massinger uses many references of binary oppositions to spotlight upon the idea of the self versus the other, distorting the image of Islam and Muslims. In Saussure's point of view, binary opposition "is the contrast between two mutually exclusive terms, such as on and off, up and down, left and right. Binary opposition is an important concept of structuralism, which sees such distinctions as fundamental to all language and thought"(Baldick, 2004: 1056-binaryopposition.html). Massinger reveals Grimaldi' as a womanizer and a kidnapper although he is to be a Muslim and Islam bans doing such things.

In a dialogue between Francisco and Vitelli, hatred and contempt for Muslims is very clear:

Francisco: I saw the shame of Venice and the scorn

Of all good men: The perjured Renegado Antonio Grimaldi;

Vitelli: Ha! his name is poison to me

Francisco: This debauched villain: whom we ever thought, (To me as I stood at the Holy Altar) The thief that ravished your fair sister from you (Massinger,1976, act I, scene i: 18)

Moreover, Massinger depicts Donusa as "veiled" to, indirectly, say that Islam is a religion of darkness and mystery while Christianity is a religion of light and clarity to deepen the idea of the self, symbolized by Christianity and the other represented by Islam. This idea is highlighted when "Donusa" asked her maid [Carazie] to tell her about the life in England. The maid told her princess that English women had more freedom than Muslim ones, to the extent that English women could have boyfriends besides their husbands. Thus, Donusa turns shaky and unconvinced of Isalm.

Donusa: Thou Carazie. Wert born in England, what's the custom there

Among your women

Donusa :I have heard That Christian Ladies live with much more freedom Than such as are born hereCarazie: But to your question Madam, women in England, for the most part, live like Queens.....

Donusa:... Your City Dame Without leave wears the breeches, has her husband At as much command as her Prentice, and if need be Can make him Cuckold by her Father's CopyWe enjoy no more. That is of the Ottoman race, though

\section{our Religion Allows all Donusa .pleasure}

I am dull, some Music .. So, a lusty strain (Massinger, I, ii: 25)

Moreover, Donusa's veil is used as a religious symbol, whereas it is from Islamic point of view the symbol of chastity which aims to protect women. Still, in all religions, until our recent times, veil is worn by Christian nuns, but no one considers it negatively. While in Massinger's point of view, the recurrent references to the veil of Muslim women show the narrow-mindedness of Islam as a way of constraining the Muslim female's freedom!

Donusa, for example, states that "Our jealous Turks" never permit their fair wives to be seen except for being at the public Bagnios, or the Mosques and even then veiled, and guarded (I, ii, 26). Again the Muslim character represented by the word "Turks" falls in the distorted stereotype as jealous. Massinger deliberately portrays Muslim characters as voluptuous; "Asambeg, the Viceroy of Tunis" falls in love with a Christian lady, instead of a Muslim one, without thinking rationally just because of her prettiness, so he is driven by passion:

Asambeg: I tremble at her softness. But only named Paulina

and the charm Had almost choked my fury 
...Appear bright spark Of all perfection: any simile Borrowed from Diamonds, or the fairest stars To help me to express, how dear I prize The unmatched graces (Massinger, II, v, 35)

On the other hand, the Western lady is presented positively; not only the virtuous Paulina refuses Asambeg's love, but also insults him and his religion, describing Islam as being false. In addition, she tells him that she prefers death to get married to him:

Asambeg: I will be your nurse, Your woman, your physician, and your fool, till with your free consent, which I have vowed never to force, you grace me with a name that shall supply all these.

Paulina: What is 't?

Asambeg: Your husband

Paulina: My hangman when thou pleases (II, v,37)

Contrastingly, Massinger shows us "Donusa" as a person guided by lust when she hands her heart to a Christian man [Vitelli] and turns to a Christian instead of making Vitelli a Muslim:

Donusa: My suit is that you would quit your shoulders of a burden under whose ponderous weight you wilfully have too long groaned, to cast those fetters off, with which with your own hands you chain your freedom

Vitelli: You speak in riddles?

What burden, .... Are those you point atDonusa :Those which your religion compels you to bear with slave-like patience.,

Donusa : Be wise, and weigh the prosperous success of things if blessings(IV, iii, 77).

The religious discrimination then is presented overtly by a direct reference to Prophet Mohammad, peace be upon him, when the Christian Vitelli insulted all Muslims' dignity by claiming that their messenger is a devil!, and that the Holy Qu'ran is just his own composition, not a divine message from Allah the only one lord:

Vitelli : But that I know .The Devil thy Tutor [a reference to Prophet Mohammad, peace be upon him] fills each part about thee .That great omnipotence at whose nod the fabric of the World shakes. Dare you bring your juggling Prophet in comparison with that most inscrutable, and infinite essence That made this all, and comprehends his work? Whose only name is sacred .I will not foul my mouth to speak the Sorceries Of your seducer, his base birth, his whoredoms, His strange impostures; nor deliver how He taught a Pigeon to feed in his ear, Then made his credulous followers believe It was an Angel that instructed him In the framing of his Alcoran. Pray you mark me (IV, iii, 77)

Donusa easily leaves Islam without paying any attention to Asambeg's threat of executing her if she fails to do so. Massinger wants to say that Muslims are not true believers, driven by eroticism as if Muslims have shaky beliefs in Islam and their prophet Muhammad:

Donusa: I came here to take you

But I perceive a yielding in myself To be your prisoner. Vitelli: O Donusa, Die in my faith like me, and 'tis a marriage

At which celestial Angels shall be waiters, And such as have been Sainted welcome us, Are you confirmed?

Donusa: I would be; but the means That may assure me?....

Then thus I spit at Mahomet. (IV, iii, 78)

From this biased perspective, Vitelli enjoyed all the positive characteristics of the self ; he is a Christian, westerner, virtuous, good whereas, the Oriental character "Donusa" is seen as the Other.

The same religious bias goes on towards the ending of the play when Philip Massinger presents converting Donusa into Christianity from Islam as giving her another life, whereas Islam is presented as death and prison. Again, the opposition between Christianity and Islam is represented as Lifeldeath opposition:

Donusa: I am another woman, till this minute I never lived, nor durst think how to die. How long have I been blind .Let me kiss the hand that did this miracle, and seal my thanks upon those lips from whence these sweet words vanished that freed me from the cruelest of prisons, blind ignorance, and misbelief: false Prophet, impostor Mahomet. (V,iii, 85)

It is obvious, then, that Massinger's deliberate distortion of Islam assures the concept of "the self" as opposed to "the other". In other words, the binary opposition of PaulinalDonusa; the stable Christian Paulinais "the self" ; however, the Muslim unstable Donusa is the "other".

The last example of Islam distortion can be shown through the hero of this play, "Grimaldi the renegade" who, again, goes back to Christianity. As if Massinger says that "Grimaldi" doesn't find deliverance and safety in Islam, and therefore converts to Christianity:

Grimaldi: I must be honest too do I owe. A peace within here, Kingdoms could not purchase, To my religious creditor, to leave him. Open to danger

.....My Father!

Francisco: My good convert

Grimaldi: Days Provided, that my stay may do you serviceBut to me shall be minutes

Francisco: I much thank you

Grimaldi: I am nothing

But what you please to have me be

Francisco: Farewell sir (V, ii, 82) 


\section{The InTERSECTION BETWEen the StRUCtURE OF THE Play AND THE THEMES}

Sixteen plays out of the eighteen, as the rest of Massinger's thirty-three plays, ones were written by Massinger in collaboration with Fletcher, so there is no wonder, then, to find Massinger's adoption of Fletcher who favored the tragicomedy to write about (Gibson, 1978: $\mathrm{x}$ )

Massinger's “The Renegado", written in 1624 and published in 1630 (Merriam-Webster, 1995: 736), exemplifies the tragi-comedy that connects both comic and tragic elements together. It has people from the upper class to refer to tragedy and others from the lower class to indicate comedy. ... Tragicomedy ends happily despite containing unpleasant situations, disguise, and eroticism (Abrams, 1981: 205). The structure of the play is in compliance with its main theme. Why not, and Massinger enjoys underestimating the Muslim characters. To achieve this purpose, the writer uses different techniques, sometimes directly, at other times symbolically. Even the method of characterization manifests this formula of opposition in many aspects: The self $\backslash$ the other, the Christian $\backslash$ the Muslim, the noblelvillain, the believer $\backslash$ the convert ....etc.

Moreover, Massinger's upper-class personas include the Muslim “Asambeg”, the Viceroy of Tunis, the Muslim "Basha Mustafa", and the Muslim Princess "Donusa", attributing them with hopelessness, shakiness, and powerlessness due to Islam. In Massinger's point of view, these characters deserve such negative descriptions to show that Islam is no longer a valid dogma to adopt, that is again to pin-point the concept of "the other." Nevertheless, the lower class personas are Paulina, her brother Vitelli, and the renegade Grimaldi who find hopefulness and confidence, and strength in Christianity to refer to "the self". In other words, happy ends are linked to the Christian characters who represent the lower class, but sad ones are linked to the Muslim characters who stand for the upper class. As a result, the western hatred of Islam is apparent via constructing the tragi-comedy as the structure of this play.

\section{CONCLUSION}

This paper sheds light on the concept of "the self and the other" through Philip Massinger's on-purpose distortion of Islam in his tragicomedy, "The Renegado". Doing so, Massinger satisfies the covetousness of the Jacobean audience who think that they are the true believers, while the non-Christians are false ones. Adapting the distorted racial view of Islam, Massinger dehumanizes Muslims in "The Gentleman of Venice" or "The Renegado". As seen, the biased image against Muslims is very clear as the ending proves the superiority of the westerners leasterners who are presented within a range of binary opposite ranking forms; Christians $\backslash$ Muslims, the virtuouslthe sinners, believerslinfidels, WestlEast, goodlbad...; or in other words the selfthe other. This Islam distortion expresses the western hatred of Islam and the western religious discrimination.

\section{REFERENCES}

[1] Abrams, M.H. (1981). A Glossary of Literary Terms. New York: Holt, Rinehart, and Winston.

[2] Baldick, C. (2004). The concise Oxford Dictionary of literary terms, viewed 8 March 2011, http://www.highbeam.com/doc/1056-binaryopposition.html.

[3] Burgess, Antony. (1987). English Literature. Harlow: Longman.

[4] Carter, Ronald G., McRae, John. (1995). The Penguin Guide to English Literature: Britain and Ireland. London: Penguin.

[5] Chew, Samuel C. (1965). The Crescent and The Rose. Oxford: Oxford University Press.

[6] Cuddon, J. A. (1998). A Dictionary of Literary Terms and Literary Theory. Oxford: Blackwell.

[7] Drabble, Margret, Stringer, Jenny (eds.). (1987). The Concise Oxford Companion to English Literature. Oxford: Oxford University Press.

[8] Fraser, Russell A, Rabkin, Norman (eds.). (1976). Drama of the English Renaissance II: The Stuart Period. New York: MacMillan.

[9] Gibson, Colin.(ed). (1978). The Selected Plays of Philip Massinger. Cambridge: Cambridge University Press.

[10] Hornby, A.S. (1995). Oxford Advanced Learner's Dictionary. Oxford: Oxford University Press.

[11] Holland, David T.(ed). (1986). Encyclopedia Americana, p. 478, vol. 18. Harcourt Brace: Grolier.

[12] Massinger, Philip. (1976). “The Renegado.” The Plays of Philip Massinger. Ed. Colin Gibson. Oxford: Oxford University Press, pp 17-96.

[13] Merriam, George, Webster, Noah. (1995). Merriam-Webster Encyclopedia of Literature. Springfield, Massachusetts: Merriam-Webster Inc.

[14] Said, Edward W. (1978). Orientalism. London: Routledge \&Kegan Paul.

[15] Stapleton, Michael. (1983). The Cambridge Guide to English Literature. Cambridge: Cambridge University Press.

Hanaa Fathi Farajallah was born in the United Arab Emirats on 24/ 3 / 1979. Farajallah's Bachelor Degree in English Language and Literature was obtained in 2002 from Al-al Bayt University, Mafraq, Jordan. The Master Degree in English Literature and Criticism was gained in 2004 from Yarmouk University, Irbid, Jordan. The majoe field of study is literature and criticism.

She works as an INSTRUCTOR at Department of English Language and Literature, Ajloun University College, Balqa' Applied University. She worked as FULL-TIME LECTURER at Department of English Language and Literature, Irbid National University from 2007-2012. She published the following articles;" The Dominance of the Victorian Man over Woman in Robert Browning's ' My Last Duchess", published in 2015 by Impact: International Journal of Research in Humanities, Arts and Literature, US; "The 
Violation of the Grace's Maxims in Jordanian Newspapers Cartoons: A Pragmatic Study", published in 2015 by Journal of Literature and Linguistics, Us; Patriotism in Robert Browning's "My Last Duchess", "An Epistle Containing the Strange Medical Experience of Karshish, the Arab Physician" and "Fra Lippo Lippi": A Symbolic Perspective, published in 2018 by British Journal of Humanities and Social Sciences, UK. She has interests in literary theory, literary criticism, Victorian poetry, and drama.

Amal R. Kitishat, born in Salt city/The Hashemite Kingdom of Jordan in $26^{\text {th }}$ of May 1970. She obtained a Ph.D. in English literature from Cairo University in 2006. She is a specialist in modern and contemporary drama.

She is an Associate Professor of English Literature, a specialist in contemporary and modern English \&Irish drama. Formerly, she held the position of Head of Department of English Language and Basic Sciences at Al Balqa Applied University\Ajloun -Jordan. Currently she is a staff member in Faculty of Arts and Head of Scientific Research Unit. Her interests in scholarship include Orientalism, English and Irish drama and literary criticism; she has published many books and articles in the field of English literary studies.

Dr. Kitishat is a member in many literary professional societies such as ALECSO - Arab League Educational, Cultural and Scientific Organization which belongs to the Arab League. Dr. Kitishat is a referee for many academic journals as well as a representative for the department of English in the Deanship of Scientific Research Unit in Faculty of Arts in Imam AbdulRahman Bin Faisal University in Saudi Arabia. 